\title{
Cold Hardiness and Vernal Budbreak of Rhamnus caroliniana and the Invasive Rhamnus cathartica
}

\author{
J. Ryan Stewart ${ }^{1}$ and William R. Graves \\ Department of Horticulture, Iowa State University, Ames, IA 50011-1100 \\ Reid D. Landes \\ Department of Biostatistics, University of Arkansas for Medical Sciences, Little Rock, \\ AR 72205-7199
}

\begin{abstract}
ADDITIONAL INDEX WORDs. carolina buckthorn, Frangula caroliniana, common buckthorn, phenology, invasiveness
Abstract. Carolina buckthorn [Rhamnus caroliniana Walt. or Frangula caroliniana (Walt.) Gray] is an attractive and water-stress-resistant shrub or small tree distributed extensively in the southeastern United States that merits use in managed landscapes. Due to substantial climatic differences within its distribution (30-year normal midwinter minima range from 13 to $-8^{\circ} \mathrm{C}$ ), selection among provenances based on differences in cold hardiness is warranted. Before selections are marketed, the potential of carolina buckthorn to be invasive also merits investigation. Ecological problems resulting from the introduction of Rhamnus L. species in the United States, most notably the dominance of $\boldsymbol{R}$. cathartica $\mathrm{L}$. (common buckthorn) over neighboring taxa, are due in part to early budbreak. Consequently, we investigated depth of cold hardiness and vernal budbreak of carolina buckthorn and common buckthorn. Stem samples of carolina buckthorn and common buckthorn collected in midwinter survived temperatures as low as -21 and -24 ${ }^{\circ} \mathrm{C}$, respectively. Although the cold hardiness of carolina buckthorns from Missouri was greater than that of carolina buckthorns from Ohio and Texas on 2 Apr. 2003, there were no differences in cold hardiness of stems from Missouri and Texas on all three assessment dates in the second experiment. All plants survived at both field locations except for the carolina buckthorns from southern Texas planted in Iowa, which showed $0 \%$ and $17 \%$ survival in 2003 and 2004 , respectively. Budbreak of both species with and without mulch in Ames, Iowa, was recorded from 9 Apr. to 10 May 2002. Mean budbreak of common buckthorn was 5.7 days earlier than budbreak of carolina buckthorn, and buds of mulched carolina buckthorns broke 4.2 days earlier than did buds of unmulched carolina buckthorns. We conclude that the cold hardiness of carolina buckthorn is sufficient to permit the species to be planted outside of its natural distribution. Populations of carolina buckthorn in Ohio and Missouri should be the focus of efforts to select genotypes for use in regions with harsh winters. Phenology of its budbreak suggests carolina buckthorn will not be as invasive as common buckthorn, but evaluation of additional determinants of invasiveness is warranted.
\end{abstract}

Rhamnus caroliniana (carolina buckthorn or indian cherry) is a widely distributed, attractive shrub or small tree indigenous across the southeastern United States. This open-crowned species averages $12 \mathrm{~m}$ in height at maturity and has glossy leaves with distinctive autumnal color (Dirr, 1998; Graves, 2002). Recent interest in promoting carolina buckthorn as a nursery crop is due to its ornamental features, its resistance to drought and flooding (Stewart and Graves, 2004), and the ease with which it can be propagated vegetatively (Graves, 2002) and sexually (Stewart and Graves, 2005). Due to the extensive natural distribution of carolina buckthorn, it is possible that genotypes from northern populations could be selected for use where winters are more harsh than those where the species is native. Within the northern portion of its native range in central Missouri, carolina buckthorn is exposed to 30 -year normal midwinter minima ranging from -6 to $-8{ }^{\circ} \mathrm{C}$ (National Climatic Data Center, 2005). In contrast, the species also occurs in central Florida, where the normal midwinter minima range from 11 to $13{ }^{\circ} \mathrm{C}$ (National Climatic Data Center, 2005).

Although winter temperatures influence the distribution of many woody species (Grace, 1987), the cold hardiness of some species is greater than that required by the climate of their natural range (Flint, 1972; Parker, 1963). Taxodium distichum (L.) L.C. Rich. has a southerly native distribution in the United States, but

Received for publication 22 Dec. 2005. Accepted for publication 24 Feb. 2006. 'Present address: Dept. of Natural Resources and Environmental Sciences, Univ. of Illinois at Urbana-Champaign, Urbana, IL 61801. has been grown as far north as Syracuse, N.Y. (Dirr, 1998). Stems of Alnus maritima (Marsh.) Muhl. ex Nutt. have survived $-80^{\circ} \mathrm{C}$ during trials in a laboratory, and plants have overwintered in Minnesota where 30-year normal midwinter minima are -16 to -20 ${ }^{\circ} \mathrm{C}$ (Schrader and Graves, 2003; National Climatic Data Center, 2005). The capacity of A.maritima to tolerate such temperatures is remarkable considering that the species occurs only in Oklahoma, Georgia, and on the Delmarva Peninsula, where the 30-year normal mimina are 0 to $-3{ }^{\circ} \mathrm{C}$ (National Climatic Data Center, 2005). Intraspecific variation in cold hardiness correlates with latitude for some temperate woody species (Flint, 1972). For example, Fraxinus americana $\mathrm{L}$. from northern provenances was more cold hardy than were conspecific plants from southern provenances (Alexander et al., 1984). Researchers studying Quercus rubra L. (Flint, 1972) and Pinus strobus L. (Lu et al., 2003) have shown similar trends. Selections of carolina buckthorn could be suitable for horticultural use in regions with harsh winters if their cold hardiness is sufficient.

In conjunction with assessing the cold hardiness of carolina buckthorn, concerns about its potential to be invasive need to be addressed. Indeed, out of 235 woody species introduced for ornamental horticultural purposes in North America, $82 \%$ were found to be colonizing outside of cultivation (Reichard, 1997). Two members of the Rhamnus L. genus, R. cathartica (common buckthorn), and $R$. frangula L. (glossy buckthorn), were introduced into the northeastern United States and the maritime provinces of Canada in the 1800s (Gourley, 1985; Wyman, 1971). After a lag time of several decades, they escaped cultivation, naturalized, and 
have aggressively spread throughout the northern United States (Catling and Porebski, 1994; Gourley, 1985).

One reason common buckthorn invades natural areas is its relatively high seasonal carbon gain that is a consequence of early vernal budbreak and foliation relative to neighboring deciduous species in the understory. Mean duration of foliation of common buckthorn exceeds that of native shrubs by up to $58 \mathrm{~d}$ (Barnes, 1972). Harrington et al. (1989) found that $29 \%$ of the annual carbon gain of common buckthorn occurred before leaf emergence of the native Cornus racemosa Lam. in Wisconsin. Early leaf emergence of common buckthorn was deemed more important to invasiveness than was late foliar senescence (Harrington et al., 1989). In comparison to a native congener, Lonicera sempervirens L., Schierenbeck and Marshall (1993) found that a long period of foliation contributed to the invasiveness of Lonicera japonica Thunb. Similar conclusions were made by Farnsworth and Meyerson (2003) concerning invasions of Phragmites australis (Cav.) Trin. ex Steud. and Typha angustifolia L. in wetlands.

Congeneric pairs often are studied to predict traits responsible for invasiveness (Gerlach and Rice, 2003; Mack, 1985; Schierenbeck and Marshall, 1993). Because its invasiveness in regions of the United States with harsh winters is well documented, common buckthorn is an ideal congeneric model species for horticultural and ecological assessments of carolina buckthorn. Our objectives were 2-fold. First, we determined the depth of cold hardiness of plants of carolina buckthorn from different provenances in comparison to that of common buckthorn in a common garden experiment to test genetic variation of these traits. Second, we compared the timing of budbreak of the two buckthorn species planted in the upper midwestern United States with and without organic surface mulch. We hypothesized that covering young plants with leaf mulch would hasten vernal budbreak because mulch can moderate soil and air temperatures (Harris et al., 1999). In addition, our leaf-mulch treatment was intended to mimic both the use of organic mulch in managed landscapes and the presence of leaf litter in natural ecosystems. Analysis of budbreak of mulched and unmulched plants provided insights regarding the potential invasiveness of carolina buckthorn. Moreover, our data will benefit horticulturists seeking information on potential new nursery crops and will aid ecologists interested in the traits associated with the invasiveness of certain Rhamnus species.

\section{Materials and Methods}

Cold HARDiness. Common buck thorns and carolina buckthorns grown from seed from three provenances were established in a plot near Ames, Iowa, on 2 Aug. 2002. Plants were irrigated every 2 to $3 \mathrm{~d}$ from 2 Aug. to 4 Oct. 2002. The plants were used in the first of two experiments during Fall, Winter, and Spring 2002-03. Samples of stems developed in 2002 were collected in Ames on 5 Oct. 2002 and 11 Jan. and 2 Apr. 2003 from three 2-year-old, half-sibling groups of common buckthorn and from 2-year-old, half-sibling groups of carolina buckthorn from three provenances:

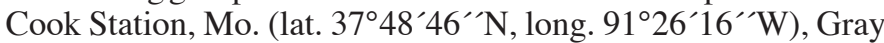


ty, Ohio (lat. $38^{\circ} 40^{\prime} 25^{\prime \prime} \mathrm{N}$, long. $83^{\circ} 27^{\prime} 10^{\prime \prime} \mathrm{W}$ ), and Kerrville, Texas (lat. $30^{\circ} 02^{\prime} 50^{\prime \prime} \mathrm{N}$, long. $99^{\circ} 08^{\prime} 24^{\prime \prime} \mathrm{W}$ ). We considered the two locations in Missouri the same provenance because they are within $160 \mathrm{~km}$ of each other (Hartmann et al., 1990). The common buckthorns were from naturalized populations in Ames, Iowa (lat. $42^{\circ} 2^{\prime} 5^{\prime \prime} \mathrm{N}$, long. 93 $37^{\prime} 11^{\prime \prime} \mathrm{W}$ ). Each half-sibling group was four plants with the same maternal parent. We used a data logger
(modelCR10X; Campbell Scientific, Logan, Utah) equipped with a probe (model CS500; Campbell Scientific) to determine daily minimum temperatures at the research site. Thirty-year normal daily minima of the research and collection sites were obtained from the National Climatic Data Center (2005).

Sample twigs were put on ice and prepared on most sampling dates within $48 \mathrm{~h}$ of collection. We cut each stem section to 4 $\mathrm{cm}$ in length after removing the terminal $2 \mathrm{~cm}$ of the distal end. Each section then was wrapped in moistened filter paper and inserted into a 16-mm-diameter culture tube that was held at 4 ${ }^{\circ} \mathrm{C}$ in a programmable freezer (ScienTemp, Adrian, Mich.) until the initiation of temperature ramping. We monitored freezer temperature by using a data logger (model CR23X; Campbell Scientific) and six type-T thermocouple wires arranged throughout the freezer. After all stem sections were prepared, the freezer temperature was lowered to $-2{ }^{\circ} \mathrm{C}$ over $15 \mathrm{~min}$. and held at -2 ${ }^{\circ} \mathrm{C}$ for $14 \mathrm{~h}$ to promote ice nucleation. Control samples then were removed and placed in a refrigerator at $4{ }^{\circ} \mathrm{C}$, and then the freezer temperature was lowered at $-2{ }^{\circ} \mathrm{C}$ per hour. Four tube-enclosed stem sections per source plant were removed at intervals of -4 ${ }^{\circ} \mathrm{C}$. Removed samples were thawed on ice for $1 \mathrm{~h}$ and held in a refrigerator at $4{ }^{\circ} \mathrm{C}$ for $12 \mathrm{~h}$. Thawed tubes were covered with parafilm and incubated in a dark growth chamber at $22{ }^{\circ} \mathrm{C}$ for $14 \mathrm{~d}$. After incubation, each sample was cut longitudinally and deemed alive (if green) or dead (if brown) based on discoloration of the cambium and phloem. Any stem material that was found dead upon collection prior to treatment initiation was ascribed a hardiness of $0{ }^{\circ} \mathrm{C}$. The stem-freezing tolerance (SFT) of each plant source was defined as the minimum temperature at which at least three of the four stem sections were alive. There were a total of three and nine experimental units of common buckthorn and carolina buckthorn, respectively, at each assessment date. Within each provenance of carolina buckthorn, there were a total of three experimental units. Survival at five temperatures was evaluated on 7 Oct. $2002\left(-4\right.$ to $\left.-20^{\circ} \mathrm{C}\right)$ and 13 Jan. $\left(-8\right.$ to $\left.-24{ }^{\circ} \mathrm{C}\right)$ and 2 Apr. $2003\left(-8\right.$ to $\left.-24^{\circ} \mathrm{C}\right)$. Survival of plants was also determined on 2 Apr. by assessing the hydration and integrity of stems, with particular attention to whether cambial tissue was tan to light green or had softened and become dark brown to black.

The second experiment was conducted during the Fall, Winter, and Spring 2003-04. Plants were established in field plots near New Franklin, Mo., and Ames, Iowa, on 28 May and 31 May 2003, respectively, and were irrigated every 2 to $3 \mathrm{~d}$. Twigs formed in 2003 were collected on 16 Oct. 2003 and 14 Jan. and 12 Apr. 2004 from three 1-year-old, half-sibling groups of common buckthorn and from three 1-year-old, half-sibling groups of carolina buckthorn from two provenances. Plants were grown from seeds of carolina buckthorn collected from three plants in Brazito, Mo. (lat. 38 $26^{\prime} 44^{\prime \prime} \mathrm{N}$, long. 92 $18^{\prime} 9^{\prime \prime} \mathrm{W}$ ) and from three plants in Kerrville, Texas. Samples also were collected from three 2-year-old, half-sibling groups of common buckthorn grown from seed collected from naturalized plants in Ames, Iowa. Each half-sibling group consisted of 10 plants with the same maternal parent. There were a total of four and eight experimental units of common buckthorn and carolina buckthorn, respectively, at each location. Within provenance, there were a total of four experimental units. Values were combined across location in order to increase the power of detecting differences. Values across location on 16 Oct. were not combined, however, due to an interaction between species and location. There were a total of eight and 16 replications of common buckthorn and carolina buckthorn, respectively, on 14 Jan. and 12 Apr. Within 
provenance and across location, there were a total of eight experimental units. Daily temperature minima were monitored at the Ames plot as during the first experiment and at the New Franklin plot with a thermometer(Max/Min Temperature System; Airflo Instrument Co., Glastonbury, Conn.). Thirty-year normal minima of the research sites in Ames, New Franklin, and the collection sites were obtained from the National Climatic Data Center (2005). Fifty-year record daily minima of the research sites were obtained from the Climatology Index Page (The Weather Channel Enterprises, 2005).

Procedures used during the first experiment were followed, beginning within $12 \mathrm{~h}$ of collection. Survival of stem sections at five temperatures was evaluated on 21 Oct. $2003\left(-4\right.$ to $\left.-20{ }^{\circ} \mathrm{C}\right)$ and 16 Jan. $\left(-8\right.$ to $\left.-24^{\circ} \mathrm{C}\right)$ and 13 Apr. $2004\left(-8\right.$ to $\left.-24^{\circ} \mathrm{C}\right)$.

Two linear models, one accounting for species effects and the other for provenance effects, were fit to the SFT data of the first experiment. Two linear models also were fit to the SFT data of the second experiment. One model accounted for effects of species, location, and their interaction. The other model accounted for effects of provenance, location, and their interaction. Analyses were conducted with the PROC MIXED procedure in SAS/STAT (version 8.2; SAS Institute, Cary, N.C.). Means were separated based on Holm's method due to the need to compare differences at the species and provenance levels (Westfall and Young, 1993).

BudBreaK. On 2 Oct. 2001, 128 carolina buckthorns and 32 common buckthorns, all 1-year-old seedlings, were planted in 16 adjacent plots near Ames, Iowa. Each plot was $1 \times 3 \mathrm{~m}$, and each plant was an experimental unit in a completely randomized split-plot design. Each plot consisted of two common buckthorns (seeds from plants naturalized in Ames, Iowa), one carolina buckthorn from Brazito, Mo., six carolina buckthorns from Adams County, Ohio, and one carolina buckthorn from Kerrville, Texas. Mulch treatments (mulch and no mulch) were randomly assigned to the whole plots, while plant species and provenance were assigned to the split plots. Fifteen centimeters of leaf $(Q$. rubra) mulch was placed on the soil surface of each plot assigned to the mulch treatment, which completely covered plants of both species. Hardware cloth (hole diameter $=2.5 \mathrm{~cm}$ ) was installed around each plot to stabilize the mulch.

We used a data logger (model CR23X) connected to eight model 107 probes (Campbell Scientific) (four per treatment) and a model CS500 probe (Campbell Scientific) to determine temperature of soil (depth $=10.2 \mathrm{~cm}$ ) of the mulched and non-mulched plots, and air, respectively, from 3 Nov. 2001 to 30 Apr. 2002. After removing mulch from the mulched treatments on 9 Apr. 2002, we monitored budbreak of the plants every 1 to $3 \mathrm{~d}$ from $9 \mathrm{Apr}$. to 10 May 2002. First day of budbreak [FDBB (the last day at which zero buds had broken)] and budbreak percentage. The first day of observation was considered to be FDBB for plants with broken buds on the first day of observation (8 out of 160). Budbreak percentage was the number of buds broken on 10 May divided by the total number of buds (BTOT) on the plant.

We fit FDBB and budbreak percentage to a linear-mixed model consisting of fixed effects of mulch, plants, the interaction of mulch and plants, and random effects of plots. There was no need to transform the raw values of budbreak percentage because there was no evidence of heterogeneity of variance. The error associated with plots was used to test the main effect of mulch. We used contrasts of effects of plants and the interaction of mulch and plants to construct tests of the main effects of provenance and species. These effects also were used to construct tests of the interactions of mulch with provenance and mulch with species.
Plants that did not survive (7 of 160) the winter were not included in the analyses, which were conducted with the PROC MIXED procedure in SAS/STAT version 8.2. The denominator degrees of freedom were calculated with the Kenward-Roger adjustment (Kenward and Rogers, 1997). We found that there was an interaction between species and mulch for both dependent variables: FDBB and budbreak percentage. We examined the effect of species at each mulch treatment for each dependent variable.

\section{Results}

Cold haRdiness. Carolina buckthorn and common buckthorn were sufficiently cold hardy on all three assessment dates during Winter 2002-03 relative to the 30-year normal minima for those dates (Table 1). Daily minima in late January and in early and late February were lower than the SFT of carolina buckthorn on 11 Jan. (Fig. 1). Common buckthorn was more cold hardy than carolina buckthorn on 5 Oct., but there were no species-level differences on 11 Jan. and 2 Apr. (Table 1). Cold hardiness of carolina buckthorns from Missouri, Ohio, and Texas was similar on 5 Oct. and 11 Jan., while plants from Missouri were most hardy and plants from Texas were least hardy on 2 Apr. (Table 1). None of the carolina buckthorns from Texas survived to resume growth during Spring 2003, but all carolina buckthorns from Ohio and Missouri and all of the common buckthorn plants survived and resumed growth.

Carolina buckthorn and common buckthorn were adequately cold hardy in both Ames, Iowa, and New Franklin, Mo., on all three assessment dates during the Fall, Winter, and Spring 2003-04 relative to the 30-year normal minima (Table 2). Daily minima in January and February were lower than the SFT of carolina buckthorn on 14 Jan. for both locations (Fig. 2). Cold hardiness of common buckthorn was greater than that of carolina buckthorn on 16 Oct. in New Franklin, but not in Ames (Table 2 ). Cold hardiness of common buckthorn across locations was also greater than that of carolina buckthorn on 14 Jan. (Table 2 ). There were no differences in cold hardiness across locations between carolina buckthorns from Missouri and Texas on all

Table 1. Stem-freezing tolerances $\left({ }^{\circ} \mathrm{C}\right)$ of 2 -year-old Rhamnus cathartica (common buckthorn) and $R$. caroliniana (carolina buckthorn) native to Missouri, Ohio, and Texas, and established in Ames, Iowa. Values of species are means of three and nine replications of $R$. cathartica and $R$. caroliniana, respectively, at each assessment date. Values partitioned by provenance are means of three replications. Survival percentages were based on visual assessments of stem viability on 2 Apr. Thirty-year normal daily minimum temperature data for Ames, Iowa, of each month are provided with the 50-year-record daily minimum temperature in parentheses.

\begin{tabular}{lccrr}
\hline Species and & \multicolumn{3}{c}{ Date 2002-03 } & Survival \\
\cline { 2 - 4 } population & 5 Oct. & 11 Jan. & 2 Apr. & $(\%)$ \\
\hline$R$. cathartica & $-13 \mathrm{~B}^{\mathrm{z}}$ & $-24 \mathrm{~A}$ & $-17 \mathrm{~A}$ & 100 \\
$R$. caroliniana & $-5 \mathrm{~A}$ & $-21 \mathrm{~A}$ & $-12 \mathrm{~A}$ & 67 \\
$\quad$ Missouri & $-5 \mathrm{a}^{\mathrm{y}}$ & $-24 \mathrm{a}$ & $-21 \mathrm{c}$ & 100 \\
$\quad$ Ohio & $-7 \mathrm{a}$ & $-24 \mathrm{a}$ & $-13 \mathrm{~b}$ & 100 \\
$\quad$ Texas & $-3 \mathrm{a}$ & $-16 \mathrm{a}$ & $0 \mathrm{a}$ & 0 \\
$\begin{array}{l}\text { Daily minimum } \\
\text { temperature }\end{array}$ & $7(-2)$ & $-13(-28)$ & $1(-8)$ & \\
\hline
\end{tabular}

${ }^{2}$ Species means within each column followed by the same capital letter are not different at $P<0.05$ according to Holm's method.

yPopulation means within each column followed by the same lower-case letter are not different at $P<0.05$ according to Holm's method. 


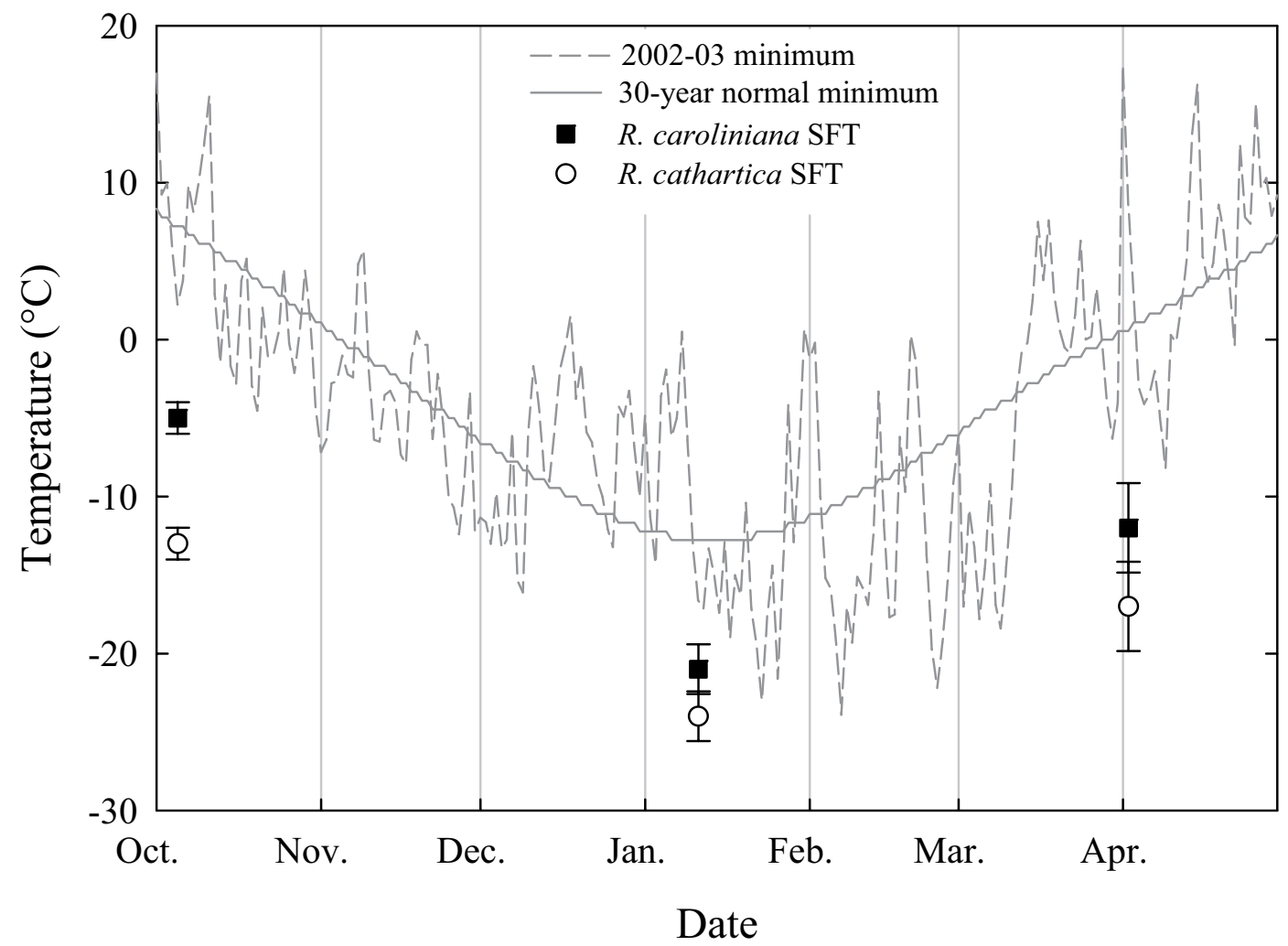

Fig. 1. Daily mininum temperatures for 2002-03 and 30-year normal minimum temperatures in Ames, Iowa, of October through April in addition to the stem-freezing tolerances (SFT) of 2-year-old Rhamnus caroliniana and R. cathartica, which were assessed on 5 Oct. 2002 and 11 Jan. and 2 Apr. 2003. Data points are mean values \pm SE.

Table 2. Stem-freezing tolerances $\left({ }^{\circ} \mathrm{C}\right.$ ) of Rhamnus cathartica (common buckthorn) and $R$. caroliniana (carolina buckthorn) native to Missouri and Texas, and established in Ames, Iowa, and New Franklin, Mo. Values of species within location are means of four and eight replications of $R$. cathartica and $R$. caroliniana, respectively, on 16 Oct. Values partitioned by provenance within location are means of four replications. Values across location on 16 Oct. were not combined due to an interaction between species and location. Values of species are means of eight and 16 replications of $R$. cathartica and $R$. caroliniana, respectively, on 14 Jan. and 12 Apr. Values partitioned by provenance are means of eight replications. Survival percentages were based on visual assessment of stem viability on 12 Apr. Thirty-year normal minimum temperature data of each month of Ames, Iowa, and New Franklin, Mo., are provided with the 50-year-record minimum temperature in parentheses.

\begin{tabular}{|c|c|c|c|c|c|c|}
\hline \multirow[b]{3}{*}{ Species and population } & \multicolumn{4}{|c|}{ Date 2003-04 } & \multirow{2}{*}{\multicolumn{2}{|c|}{ Survival (\%) }} \\
\hline & \multicolumn{2}{|c|}{16 Oct. } & \multirow[b]{2}{*}{14 Jan. } & \multirow[b]{2}{*}{12 Apr. } & & \\
\hline & Ames & New Franklin & & & Ames & New Franklin \\
\hline R. cathartica & $-11 \mathrm{~A}^{\mathrm{z}}$ & $-15 \mathrm{~B}$ & $-24 \mathrm{~B}^{\mathrm{y}}$ & $-4 \mathrm{~A}$ & 100 & 100 \\
\hline R. caroliniana & $-8 \mathrm{~A}$ & $-1 \mathrm{~A}$ & $-17 \mathrm{~A}$ & $-1 \mathrm{~A}$ & 59 & 100 \\
\hline Missouri & $-6 a^{x}$ & $-6 a$ & $-16 \mathrm{a}$ & $-1 \mathrm{a}$ & 100 & 100 \\
\hline Texas & $-2 \mathrm{a}$ & $-2 \mathrm{a}$ & $-18 \mathrm{a}$ & $-1 \mathrm{a}$ & 17 & 100 \\
\hline \multicolumn{7}{|c|}{ Daily minimum temperature } \\
\hline Ames & $5(-4)$ & & $-13(-29)$ & $3(-7)$ & & \\
\hline New Franklin & & $7(-2)$ & $-8(-23)$ & $6(-6)$ & & \\
\hline
\end{tabular}

${ }^{2}$ Location means within species within the 16 Oct. columns followed by the same capital letter are not different at $P<0.05$ according to Holm's method.

ySpecies means within each column followed by the same capital letter are not different at $P<0.05$ according to Holm's method.

xPopulation means within each column followed by the same lowercase letter are not different at $P<0.05$ according to Holm's method. 


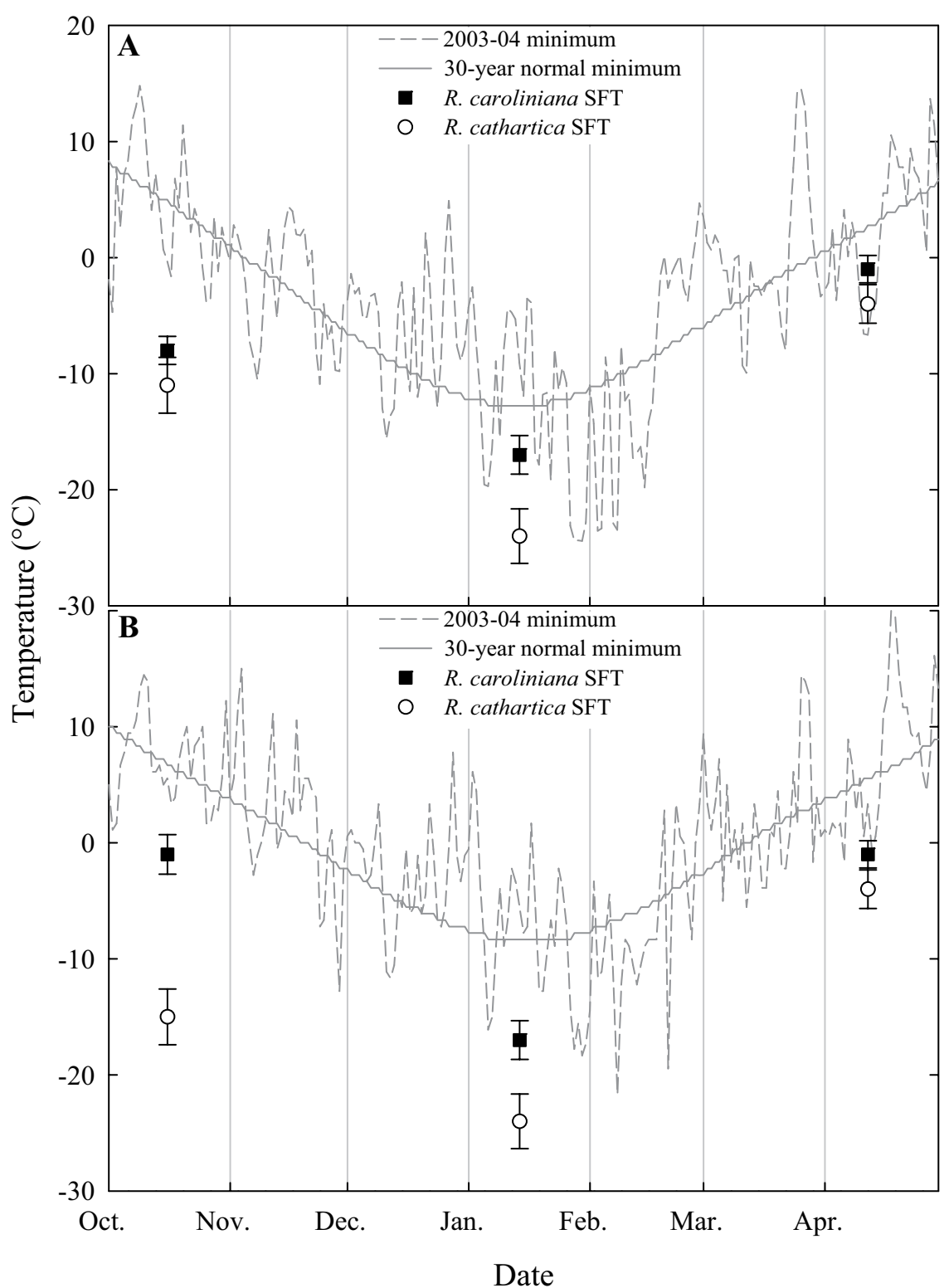

Fig. 2. Daily mininum temperatures of 2003-04 and 30-year normal minimum temperatures in Ames, Iowa (A), and New Franklin, Mo. (B), in addition to the stem-freezing tolerances (SFT) of 1-year-old Rhamnus caroliniana and $R$. cathartica, which were assessed on 16 Oct. 2003 and 14 Jan. and 12 Apr. 2004. Values across location on 16 Oct. were not combined due to an interaction between species and location. Data points are mean values $\pm \mathrm{SE}$.

three assessment dates, but only $17 \%$ of the plants from Texas planted in Ames, Iowa, survived into April (Table 2). All plants from Missouri, however, survived and resumed growth during Spring 2004.

BUDBREAK. Mean minimum soil temperature in mulched plots over the winter and spring was 0.7 to $7.4{ }^{\circ} \mathrm{C}$ greater than that of unmulched plots. The FDBB of common buckthorn ( $4.6 \mathrm{~d}$ after 9 Apr.) was not influenced by mulch and was earlier than that of carolina buckthorn [no mulch $=12.4 \mathrm{~d}$ after 9 Apr. $(P<0.0001)$, mulch $=8.2 \mathrm{~d}$ after 9 Apr. $(P=0.02)]$. Carolina buckthorns broke bud earlier when mulched than when not mulched $[8.2 \mathrm{~d}$ after 9 Apr. vs. $12.4 \mathrm{~d}$ after 9 Apr. $(P=0.005)]$. There were no differences in the FDBB among carolina buckthorns from the three provenances $(P=0.37)$.

There was no mulch effect $(P=0.75)$ on the total percentage of broken buds of common buckthorn $(92 \%)$, but $91 \%$ of buds broke on mulched carolina buckthorns, while only $61 \%$ of buds broke on plants without mulch $(P=0.0004)$. The budbreak percentage of common buckthorn $(92 \%)$ was greater than that of carolina buckthorn $(61 \%)$ in the unmulched treatment $(P<0.0001)$. There was no difference, however, in the total percentage of broken buds between mulched plants of the two species $(P=0.59)$. Only $38 \%$ of the unmulched carolina buckthorns from Texas survived, whereas $88 \%$ of the mulched plants from Texas survived. All carolina buckthorns from Missouri, regardless of treatment, and all unmulched plants from Ohio survived, while $98 \%$ of the mulched plants from Ohio survived.

\section{Discussion}

These data represent the first information on the potential cold hardiness of carolina buckthorn. Our approach was to plant seedlings from disparate provenances in central Missouri, near the northern limit of the geographical distribution of carolina buckthorn, and in central Iowa, $\approx 360 \mathrm{~km}$ to the northwest of the northern natural limit for the species. We designed our experiments to permit comparisons of carolina buckthorn and common buckthorn, an invasive Eurasian member of the same genus that is naturalized in both Missouri and Iowa. Common buckthorn is cold hardy throughout the upper midwestern United States and thus served as a control to ensure the reliability of our methods.

Conclusions regarding cold hardiness can be drawn based on SFT determinations made in October, January, and April in the laboratory and on survival in the field. If we ignore differences among provenances of carolina buckthorn and make comparisons at the species level, the primary difference is that carolina buckthorn is less cold hardy than is common buckthorn during early and mid-October. Nonetheless, we also conclude that plants from all three provenances of carolina buckthorn we studied have the potential to survive winters harsher than those associated with their native habitats. Although further evaluation is needed, our data support the conclusion that the geographical area beyond the natural distribution in which cold hardiness will permit the safe use of carolina buckthorn in managed landscapes varies with provenance of the germplasm.

Analyses showed the SFT of carolina buckthorn averaged over provenances was $8{ }^{\circ} \mathrm{C}$ higher in Oct. 2002 and 3 and 14 ${ }^{\circ} \mathrm{C}$ higher in Ames and New Franklin, respectively, in Oct. 2003 than the SFT of common buckthorn (Tables 1 and 2). Carolina buckthorn and common buckthorn showed similar SFTs at three of the four other measurement dates of both experiments, but the SFT of carolina buckthorn was $7{ }^{\circ} \mathrm{C}$ higher than the SFT of common buckthorn in mid-January of 2004 (Table 2).

The higher SFTs of carolina buckthorn in October of both years may be due to genetically controlled patterns of cold 
acclimation related to the photoperiod and temperatures found in the geographic range of carolina buckthorn. Increased cold hardiness of temperate woody plant species generally develops long before the lowest temperatures associated with the region occur (Kozlowski and Pallardy, 2002). Although the October SFTs of carolina buckthorn were higher than those of common buckthorn, there were no differences in SFT of the two species at other dates except for 14 Jan. 2004 (Tables 1 and 2).

Regardless, carolina buckthorn was sufficiently hardy in October to withstand the 50-year-record daily minima of both dates (Tables 1 and 2). Primary differences between the seasonal cold hardiness of both species may be related to provenance differences of sampled material of carolina buckthorn. Indeed, the Apr. 2003 survival rate of carolina buckthorns from Texas in 2004 was $0 \%$ (Table 1), and our decision to ascribe the hardiness of $0{ }^{\circ} \mathrm{C}$ to stem material from Texas, which was dead upon collection in April, likely resulted in a conservative estimate of its hardiness. There may be substantial variation in cold hardiness among provenances of woody plant species (Cannell and Sheppard, 1982; Schrader and Graves, 2003). The true cold hardiness of many woody plant taxa has often been underestimated and is often greater than assumed for many woody plant species with wide geographic ranges (Flint, 1972). Carolina buckthorn conforms to this pattern, but the difference between our estimates of its actual hardiness and the hardiness it would need to persist in the harshest portions of its native range is not as great as exists for some other taxa (Schrader and Graves, 2003). Differences in deacclimation patterns of plants from the different provenances need to be considered. Deacclimation, an important aspect of the overall cold hardiness of a plant (Arora et al., 2004), of the carolina buckthorns from Texas may have resulted in higher freeze-kill when low temperatures returned after transient warming spells.

Annual normal daily minima associated with the provenances of carolina buckthorn we used range from $0{ }^{\circ} \mathrm{C}$ (Kerrville, Texas) to $-8^{\circ} \mathrm{C}$ (Brazito, Mo.), and our observations over two years indicate that each provenance of carolina buckthorn we studied has the potential to persist when planted in regions in which normal daily minima are lower than those of the native habitat. For example, $100 \%$ of plants indigenous to southern Texas survived the winter of 2003-04 in central Missouri (Table 2), and all plants indigenous to southern Ohio (Table 1) and central Missouri (Tables 1 and 2) survived in central Iowa. Although SFT data show that carolina buckthorns from all provenances were sufficiently hardy at each sampling date to withstand the normal daily minima of Ames and New Franklin, our SFT data suggest carolina buckthorns would not survive the 50-year-record minima for Ames in January (Tables 1 and 2) and of both locations in Apr. 2004 (Table 2).

This illustrates the possibility that carolina buckthorns planted at sites where winter conditions are similar to those in Ames and New Franklin might be damaged or killed during unusually harsh winters. We may have, however, underestimated the mid-winter hardiness of carolina buckthorns from Missouri and Ohio in Jan. 2003; the SFT estimate of $-24{ }^{\circ} \mathrm{C}$ for plants of both provenances was the lowest temperature to which we subjected stems (Table 1). For the same reason, our SFT estimates of common buckthorn in January of both years may be too conservative. This potential cause for underestimates does not apply to Apr. 2004, however, because survival was tested at temperatures lower than the SFT we subsequently determined.
Future examination of variation in depth of hardiness in response to ambient conditions in field trials covering a wide geographic area may be one way to reconcile the SFT estimates of common buckthorn that are higher than the record daily minima with the extensive climatic range of the region it has invaded throughout the northeastern United States and southern Canada. The second stage of cold hardening is dependent on ambient winter temperatures (Weiser, 1970) and the degree of cold hardiness may differ throughout the winter (Levitt, 1980), from year to year (Taulavuori et al., 2004), or among locations (Schrader and Graves, 2003). Actual minima were below the SFT of common buckthorn in New Franklin in Jan. and Feb. 2004 and below that of carolina buckthorn in January and February of both years (Figs. 1 and 2). Cold hardiness appears to have increased, though, in both species based on their survival in April of both years (Figs. 1 and 2). Future work in assessing the cold hardiness of carolina buckthorn should include field trials that include numerous plant provenances and that span more than one season at multiple sites to account for variations among genotypes and in climatic patterns. It has also been shown that the cold acclimation ability of woody perennials can increase with physiological and chronological age (Lim et al., 1999). Additional work is needed to determine if reproductively mature plants of carolina buckthorn and common buckthorn exhibit lower SFT values than their 1- to 2-year-old counterparts to definitively ascertain the adaptability of these species in a given climatic zone.

Regardless of the region in which selections of carolina buckthorn are cold hardy, questions regarding its potential invasiveness merit attention due to interests in promoting its use in managed landscapes. The delayed budbreak of carolina buckthorn relative to that of common buckthorn provides some evidence to support the hypothesis that invasiveness potential of carolina buckthorn is comparatively low. Early budbreak of common buckthorn contributes to its invasiveness (Harrington et al., 1989). Even with leaf mulch, which insulated the soil, the FDBB of carolina buckthorn was later than that of common buckthorn. We have observed that carolina buckthorn is typically found in understory habitats in its native range. Harrington et al. (1989) concluded that early budbreak of common buckthorn in a Wisconsin forest helped promote its persistence in an understory habitat, but not in an open habitat. This effect was manifest in the reduced fecundity of native shade-intolerant annuals in the presence of Lonicera maackii (Rupr.) Herder in southern Ohio forests (Gould and Gorchov, 2000).

Vernal phenology of carolina buckthorn appears to be controlled by environmental factors such as air temperature (Hanninen, 1991) than by developmental constraints; total percentage of broken buds was greater for mulched carolina buckthorns than for those in the non-mulched treatment. Although documenting the leaf longevity of carolina buckthorn during the entire growing season would be valuable, our data on vernal budbreak represent an important component of the information useful for predicting the invasiveness of the species. Timing of budbreak of carolina buckthorn indicates that it might be less invasive than common buckthorn, but other factors also need to be considered before promoting its use in the landscape and nursery industries. These factors include fruit set and dispersal (Godwin, 1936; Kollmann and Pirl, 1995), seed germinability (Stewart and Graves, 2005), and vigorous plant development (Archibold et al., 1997). 


\section{Literature Cited}

Alexander, N.L., H.L. Flint, and P.A. Hammer. 1984. Variation in coldhardiness of Fraxinus americana stem tissue according to geographic origin. Ecology 65:1087-1092.

Arora, R., L.J. Rowland, E.L. Ogden, A.L. Dhanaraj, C.O. Marian, M.K. Ehlenfeldt, and B. Vinyard. 2004. Rate of dehardening, stage of bud opening, and changes in dehydrin metabolism in blueberry (Vaccinium spp.) cultivars during deacclimation at constant, warm temperatures. J. Amer. Soc. Hort. Sci. 129:667-674.

Archibold, O.W., D. Brooks, and L. Delanoy. 1997. An investigation of the invasive shrub European buckthorn, Rhamnus cathartica L., near Saskatoon, Saskatchewan. Can. Field-Naturalist 111:617-621.

Barnes, W.J. 1972. The autecology of the Lonicera X bella complex. PhD Diss., Univ. of Wisconsin-Madison.

Cannell, M.G. and L.J. Sheppard. 1982. Seasonal changes in the frost hardiness of provenances of Picea sitchensis in Scotland. Forestry 55:137-153.

Catling,P.M. andZ.S. Porebski. 1994. The history of invasion and current status of glossy buckthorn, Rhamnus frangula, in southern Ontario. Can. Field-Naturalist 108:305-310.

Dirr, M.A. 1998. Manual of woody landscape plants: Their identification, ornamental characteristics, culture, propagation, and uses. 5 th ed. Stipes Publishing, Champaign, Ill.

Farnsworth, E.J. and L.A. Meyerson. 2003. Comparative ecophysiology of four wetland species along a continuum of invasiveness. Wetlands 23:750-762.

Flint, H.L. 1972. Cold hardiness of twigs of Quercus rubra L. as a function of geographic origin. Ecology 53:1163-1170.

Gerlach, J.D. and K.J. Rice. 2003. Testing life history correlates of invasiveness using congeneric plant species. Ecol. Appl. 13:167-179.

Godwin, H. 1936. Studies in the ecology of Wicken Fen: III. The establishment and development of fen scrub (carr). J. Ecol. 24:82-116.

Gould, A.M.A. and D.L. Gorchov. 2000. Effects of the exotic invasive shrub Lonicera maackii on the survival and fecundity of three species of native annuals. Amer. Midland Naturalist 144:36-50.

Gourley, L.C. 1985. A study of the ecology and spread of buckthorn (Rhamnus cathartica L.) with particular reference to the University of Wisconsin Arboretum. MS Thesis, Univ. of Wisconsin-Madison.

Grace, J. 1987. Climatic tolerance and distribution of plants. New Phytol. 106:113-130.

Graves, W.R. 2002. IBA, juvenility, and position on ortets influence propagation of Carolina buckthorn from softwood cuttings. J. Environ. Hort. 20:57-61.

Hanninen, H. 1991. Does climatic warming increase the risk of frost damage in northern trees? Plant Cell Environ. 14:449-454.

Harrington, R.A., B.J. Brown, and P.B. Reich. 1989. Ecophysiology of exotic and native shrubs in southern Wisconsin. I. Relationship to leaf characteristics, resource availability, and phenology to seasonal patterns of carbon gain. Oecologia 80:356-367.

Harris, R.W., J.R. Clark, and N.P. Matheny. 1999. Arboriculture: integrated management of landscape trees, shrubs, and vines. Prentice-Hall,Upper Saddle River, N.J.

Hartmann, H.T., D.E. Kester, and F.T. Davies, Jr. 1990. Plant propagation: principles and practices. Prentice-Hall, Englewood Cliffs, N.J.

Kenward, M.G. and J.H. Rogers. 1997. Small sample inference for fixed effects from restricted maximum likelihood. Biometrics 53:983-997.

Kollmann, J. and M. Pirl. 1995. Spatial pattern of seed rain of fleshyfruited plants in scrubland-grassland transition. Acta Oecologica 16:313-329.

Kozlowski, T.T. and S.G. Pallardy. 2002. Acclimation and adaptive responses of woody plants to environmental stresses. Bot. Rev. 68:270-334.

Levitt, J. 1980. Responses of plants to environmental stresses. Vol. 1. Chilling, freezing, and high temperature stresses. Academic, New York.

Lim, C.-C., S.L. Krebs, and R. Arora. 1999. A 25 kD dehydrin in association with age- and genotype-dependent leaf freezing tolerance in Rhododendron. Theor. Appl. Genet. 99:912-920.

Lu, P.X., D.G. Joyce, and R.W. Sinclair. 2003. Geographic variation in cold hardiness among eastern white pine (Pinus strobus L.) provenances in Ontario. For. Ecol. Mgt. 178:329-340.

Mack, R.N. 1985. Invading plants: Their potential contribution to population biology, p. 217-242. In: J. White (ed.). Essays in honour of John L. Harper. Academic, London.

National Climatic Data Center. 2005. U.S. climate normals. U.S. Dept. of Commerce. 21 Apr. 2005. <http://www5.ncdc.noaa.gov/cgi-bin/ climatenormals/climatenormals.pl>.

Parker, J. 1963. Cold resistance in woody plants. Bot. Rev. 29:123201.

Reichard, S.H. 1997. Prevention of invasive plant introductions on national and local levels. In: J.A. Luken and J.A. Thieret (eds.). Assessment and management of plant invasions. Springer, New York.

Schierenbeck, K.A. and J.D. Marshall. 1993. Seasonal and diurnal patterns of photosynthetic gas exchange for Lonicera sempervirens and L. japonica (Caprifoliaceae). Amer. J. Bot. 80:1292-1299.

Schrader, J.A. and W.R. Graves. 2003. Phenology and depth of cold acclimation in the three subspecies of Alnus maritima. J. Amer. Soc. Hort. Sci. 128:330-336.

Stewart, J.R. and W.R. Graves. 2004. Photosynthesis and growth of Rhamnus caroliniana during drought and flooding: Comparisons to the invasive Rhamnus cathartica. HortScience 39:1280-1284.

Stewart, J.R. and W.R. Graves. 2005. Seed germination of Rhamnus caroliniana: Implications for ecology and horticulture. HortScience 40:767-770.

Taulavuori, K.M.J., E.B. Taulavuori, O. Skre, J. Nilsen, B. Igeland, and K.M. Laine. 2004. Dehardening of mountain birch (Betula pubescens ssp. czerepanovii) at elevated midwinter temperatures. New Phytol. 162:427-436.

The Weather Channel Enterprises. 2005. Climatology index page. 7 Jan. 2005. <www.weather.com/common/home/climatology.html>.

Weiser, C.J. 1970. Cold resistance and injury in woody plants. Science 169:1269-1278.

Westfall, P.H. and S.S. Young. 1993. Resampling-based multiple testing: examples and methods for P-value adjustment. Wiley, New York.

Wyman, D. 1971. Shrubs and vines for American gardens. Macmillan, New York. 